\title{
The Importance of Family Education in the New Period And Feasible Path Analysis
}

\author{
WANG Ju-qin \\ Teaching Department of the ideological and political theory \\ NCEP University \\ Baoding, China \\ ice_0613@126.com
}

\author{
LI Bao-lin \\ Teaching Department of the ideological and political theory \\ NCEP University \\ Baoding, China \\ ice_0613@126.com
}

\begin{abstract}
The new period of reform and opening up impels new changes in family characteristics, also brings new problems and challenges to the family education. Based on the new changes in the family and the new challenge family education faces, the paper highlights the importance of family education. Then it provides four viable paths of family education, including guiding the formation of stable marriage relationship, setting up the harmonious family values, building a good family education environment and carrying out parental education actively.
\end{abstract}

Keywords-new period; family education; importance; feasible path

Since the third plenary session in 1978, Chinese social development has entered into the new period of reform and opening up. As establishing the socialist market economy system and swept by the economic globalization, our society is in the ever-changing situation. As the basic components of society, the family is inevitably in the change compared with the past. Family structure, values, and the environment have had new features, especially for family education. Family used to be the main front in education, played a fundamental role in education. But now, with the education position transferred to schools and the societies, family education has been gradually weakened and further restricts the development of the whole education. It not only doesn't provide facilitation for the education of schools and societies but also becomes the shackles of the whole education. Therefore, in the new period, it is necessary to re-recognize the important role of family education in the overall education, and to reshape the important function of family education under the new social conditions.

\section{THE NEW CHANGES OF FAMILY AND NEW CHALLENGES FACED BY FAMILY EDUCATION}

"Family is a dynamic elements; it is rather advancing from low-level stage to high-level stage than standing still" [1] (Morgan 1997), Morgan once said, who is the author of "Ancient Society" and an American ethnologist. With the development of our society into a new historical era, the unprecedented changes have taken place in the family structure, values, and environment. And this is a challenge for family education.

\section{A. Changes in family structure and its challenge to family education}

Before the reform and opening up, family structure type mainly includes composite family and trunk family and particularly the trunk family is more common. After the reform and opening up, with China's transformation from a traditional society to a modern society, the nuclear family gradually replace the trunk family and become a new type of family structure. Not only that, with the natural economy replaced increasingly by commodity economy, people are freed from the bondage and the family is no longer a limiting factor in the pursuit of their own development. Thus the empty-nest families appear. Furthermore, after the reform and opening up the conservative ideology of the people are increasingly broken down by the open idea and divorce is no longer subject to the exclusion of traditional ethics. As a result, divorce rate has soared, and eventually the number of single-parent families has increased year by year. Finally, under the influence of ideas of the Western individual freedom, the traditional concept of "There are three ways to be unofficial; the worst is to not produce posterity" has been shaken increasingly. Especially DINK families have appeared in the family in which the couples have higher education level, and this tendency is tending to be fashion.

The particularity of family structure has made family education facing an unusually complex situation. More specifically: first of all, as nuclear families become the main part of the family structure, child-centered attitudes are beginning to be established. Thus two problems have been produced-one is the tendency of the marginalization of the elderly and the other is the difficulty of child education. In addition, the presence of the empty-nest families objectively caused the contact between the children and the elderly dwindling, and the estranged and fractured relationship makes the traditional culture lacking necessary constraints of family structure. Besides, the family is the cell of society, and single-parent families as a social variant cell cause severe trauma to the children psychology health, which even cause a lifetime of psychological crisis and seriously affect the normal social development of children. Finally, DINK families objectively reflect the individual freedom and independent awareness and the responsibility 
consciousness desalination, which is departing from education requirements and easy to form a personal obsession.

\section{B. Changes in family values and its challenge for family education}

"The family concept is stereotyped by the values and lifestyle in the family life and the reflection on some social life. It determines the mutual relations of the amphoteric members of the family" ${ }^{[2]}$ (Lingwei Ke 2003). Compared with the traditional social, the current family value has changed a lot. First, the traditional concept of marriage is gradually diversified. The values such as "husband guides wife" or "being faithful to one's husband unto death" have not been binding on family members any more. The deviant behavior such as "extramarital affair" and "extramarital love" had showed up. Second, the family inner core tilts gradually from men to women, and the concept of "men make houses and women make homes" is broken as female self-development space continues to expand. The modern women's awareness of the pursuit of freedom and equality are often in conflict with traditional family values, which is often prone to produce family conflicts. Third, "parental authority" is increasingly being challenged, and then blind freedom progresses to the extremes. There are quite a few examples that many children maim their parents, since excessive unrestraint may produce problems easily.

Family values are formed in the interaction of the individual values of the various members of the family, and influenced by income, occupation, marital status and other aspects. Therefore, the following should be attached more importance to. For one thing, family values are usually generated under the unified guiding ideology of the society, but specific to different families it is different. Since it is of relative independence, we should make the family education to analyze specific issues in a specific implementation. For another, once family values formed, it would have the steady characteristics. Therefore, when we conduct family education, we need to tap the main factors that affect the family values, which requires a higher demand of longitudinal study on family education.

\section{Changes in family environment and its challenge for family education}

From a different perspective, the home environment can be divided into the family soft environment, the family hard environment, the family internal environment and family external environment. The soft environment and hard environment of the family refers to the atmosphere quantifiable environmental factors. The internal and external environment of the family refers to the relationship between husband and wife, and external interpersonal relationships. The whole family environment had changed since the reform and opening up. The family environment has undergone tremendous changes. For instance: the atmosphere within the family members tends to be easy; family resource has become increasingly rich; factors that the lead to instability in the relationship between husband and wife have increased; the socialization function of the family has been strengthened constantly, etc. In short, the family environment is single and closed before the reform and opening up. But after the reform and opening up, the family environment is becoming more complex and open. All the changes in the social development are influencing the structure of the family environment.

As a micro-environment, family environment is essential for family education, because good family environment is conducive to promoting educational activities. But currently the complex and diverse family environment is in the dynamic changes, which brings massive challenges to the family education. Firstly, the research of environment is the premise of developing family education. Without the support of the environment, the educational activities could not be developed normally. Hence the complex and changing family environment needs family educators make some more in-depth and specific researches on educational environment. Secondly, since the flexibility of the family education is far less than the rate of change of the family environment, we should convert the ways of family education to adapt to the changing environmental requirements. Besides, in many cases, there are some factors that will deviate from the goals of the family education, which make a reaction force to the family education and hinder its effectiveness.

\section{THE IMPORTANCE OF FAMILY EDUCATION IN THE NEW PERIOD}

In order to adapt to the requirement of the changes in the family, it is important to highlight the importance of the family education theoretically.

\section{A. To make up for education's "short board"}

Education runs through a person's life. Although there is no specific educator, in our society, schools have been the main positions of education. Society also bears a certain responsibility for education. But it ignores the family education, which is supposed to be the most important. The emphasis on family education is nowhere near it on school and social education. Then the education's "short board" occurs. Parents once thought they were just children's logistics department. On the contrary, the first $1 / 3$ part of one's life is the most valuable stage which lays the foundation for later life and mostly contacts with family. In certain extent, family education plays a vital role in human's life, and has a direct impact on future schools and social education. Therefore, valuing family education is a direct way to make up the "short board" of education, and it can lay a good foundation for the education activities in schools and societies.

\section{B. Shaping the individual personality sound fundamentally}

A youngster whose parents were both professors was previously reported to brandish a knife and kill their parents. Then in the court, the youngster said, "Because 
my parents do not know what I really need even before they die. They do not know how to educate their children scientifically, so I killed them." ${ }^{[3](\mathrm{P5})}$ What we see is just the lack of ethics from this typical example? As everyone knows, this is an outstanding performance of the serious personality defects. Being educated well, why there is the outrageous behavior? The reason of the problem is the lack of the family education. According to a survey, onethird of family education is improper and the overprotective and overly intrusive and severely punished parents, respectively, accounted for $30 \%, 30 \%$ and $7 \%$ $10 \%$ of the total number being investigated. ${ }^{[4]}$ Therefore, it is necessary to integrate family education mode and shape the individual personality sound radically. For one thing, with respect to the age of individuals, childhood is a critical period of the shaping of the individual personality and is most closely linked with the families. Therefore, good family education from the very beginning can lay a solid foundation for the training of the sound individual personality. For another, with respect to the role of family education, schools and social education often focused on external systems and norms in conformity with the requirements of social indoctrination to the individual. Family education is more inclined to transform thinking to shape the sound individual personality.

\section{Opening up the "experimental field" of the study of educational innovation}

As we all know, some of the current educational philosophy, ways and means, and operating mechanism is old, which does not meet the actual needs of social development. Therefore, Innovative research in education has become an objective need for self-development. But compared with the family education, the school and social education affect a wider range and need to take care of parties interests and needs, so when they are conducting innovative research work, the display space of them are limited. As the cell of society, family also has an impact on society, but its spread is not very wide and even a negative impact on the general will not cause fatal consequences. So the practice of the educational innovation research can be tested first in the family field. Because it is rooted in real life, it's more practical. In a word, family education can provide a broader space for the whole educational development.

\section{THE IMPLEMENTATION OF PATH ANALYSIS OF THE FAMILY EDUCATION}

In view of the new challenges encountered by family education and the importance of family education, the crucial question is "how to do".

\section{A. Guiding the formation of a solid marriage}

In the current family structure, nuclear families accounted for the majority, which makes the marriage in the family crucial. Therefore, we should add marriage education to family education, and make both spouses know that "For a successful marriage, the most important thing is not that the couples have less conflicts and problems but they aware of that love is not an emotion but a commitment." ${ }^{[5]}$ Besides, with regard to the legal system, there are some ways for the couples to realize the legal norms they should comply, such as through brochures or case analysis. Once the legal responsibility is violated, we can strengthen the couple's the sense of married responsibility from the external binding level. Specifically, on the one hand, we should strengthen the construction of premarital counseling agencies and marriage counseling agencies so as to meet the practical needs. On the other hand, in order to reflect the role of law on the protection of the consummation of marriage, we should improve the relevant laws and regulations.

\section{B. Establishing a harmonious family values}

In actual family life, obviously, the contradictions exist between the husbands and wives or the children and elders. We are both opposed to the original "parent" hierarchy, but also against those extreme democratic practices. For this reason, in order to appease conflicts, we can establish the concept of harmony in family education. For example, we can take example by the counseling principles and make the communication effectively, which can untangle people's knots. Over time, the harmonious family values will eventually be established.

\section{Creating a good family education environment}

Family education should keep pace with the theme of harmonious, and foster harmonious family relations. We ought to prevent two extremes towards children problems: overly demanding children or over-indulgence. Family condition is a double-edged sword for the children. We should deal properly with the family resource allocation, and make it become the motivation which can promote children to grow up, rather than the obstructive factors. Besides, family education should focus on improving the overall quality of the parents, to help them master the scientific way of education. Furthermore, we ought to combine the family education with school education and social education. The Government should increase the propaganda of family education, and gradually improve its social status.

\section{Active in parenting education}

Firstly, parents should change their concepts of education, and emphasis on family education. To change the one-sided understanding of the past, which once parents pinned their hopes on school and society. Secondly, guide parents to cultivate their children according to their characteristics in different periods. For example, the physical and mental development of children showed in infancy, childhood and adolescence are different. Thirdly, we should provide some methods to the parents which can help them dealing with problems. Such as adolescent problems, violence in school and generation gap, etc. Only through these ways can parents enhance 
their abilities to educate their children, thus achieve the ultimate goal of educating.

\section{REFERENCES}

[1] Morgan.(1997). "Ancient society". The Commercial Press.

[2] Lingwei Ke, Xuexian Guo, (2003), "The impact of the reform and opening up of the family structure", The University of Zhengzhou Press, No: 01, pp:78-82.

[3] Green. (1991) ."Tutor revolution". Economic Daily Press.

[4] Two-thirds of Family Education Improper.(1999). China Youth Daily.

[5] Fang Sun, Changwei Guo, (2004), "On the ideological and political work of social transformation in family", The College of Guangxi Youth Leaders Press, No: 03, pp:10-11. 